\title{
An Ecocritical Reading of T.S. Eliot: An Approach Towards Sustainable Development
}

\section{Czytając T.S. Eliota: ekokrytyczna analiza z perspektywy zrównoważonego rozwoju}

\author{
Archana Verma, Rajni Singh
}

\author{
Department of Humanities and Social Sciences \\ Indian Institute of Technology (ISM), Dhanbad-826004, India \\ E-mails: archanaverma773@gmail.com,rajnisingh18@gmail.com
}

\begin{abstract}
T.S. Eliot's writings have always been an essential point of discussion among critics and scholars due to its diverse range of themes and his focus on the major concerns of the modern period. Eliot was a keen observer of the great transformations which the environment has endured. The present paper is an attempt towards an ecocritical reading of Eliot's poems. His works depict the major environmental challenges such as pollution, population, water scarcity, deforestation, and therefore could be interpreted as his step towards sustainable development. Though the concept of sustainable development has evolved recently, the need to create awareness towards the environment was felt at the time when Eliot's writings were in progress. Hence, an eco-critical reading of Eliot's works helps in understanding his consciousness towards the degradation of the environment and his move towards creating awareness among others.
\end{abstract}

Key words: ecocriticism, sustainable development, T. S. Eliot, environmental degradation

\begin{abstract}
Streszczenie
Świat przeszedł wielkie przemiany w ciągu ostatnich kilku dekad. Pomimo wynalezienia wspaniałych technologii, które ułatwiają ludzkie życie, dzisiejszy świat zmaga się z poważnymi problemami środowiskowymi, takimi jak zanieczyszczenie, przeludnienie, niedobór wody, zagrożenia dla zdrowia, wylesianie, ubóstwo i zanik bioróżnorodności. Rosnący zakres tych problemów był przyczyną sformułowania koncepcji zrównoważonego rozwoju. Ma on na celu pozostawienie zasobów naturalnych dla przyszłych pokoleń bez uszczerbku dla obecnych potrzeb. Chociaż idea ta została opracowana niedawno, potrzeba kreowania świadomości ekologicznej pojawiła się już w czasie rewolucji przemysłowej i dwóch wojen światowych. Jako pisarz okresu powojennego prace T.S. Eliota ukazują główne wyzwania środowiskowe i mogą być również interpretowane jako krok w kierunku zrównoważonego rozwoju. W tym świetle niniejszy artykuł jest próbą ekokrytycznej lektury wierszy tego autora.
\end{abstract}

Słowa kluczowe: ekokrytyka, zrównoważony rozwój, T. S. Eliot, degradacja środowiska

\section{Introduction}

With the onset of the twentieth century, one of the major issues for the human race was the degradation of Mother Nature. Industrialization and urbanization have collectively affected the air, water, and land. The advent of science and technology has led to the negligence of the natural environment. In 1987, a report was published by the Bruntland Commission Our Common Future, which stated the need for the balance in the degradation of the environment and asserted that sustainable development is the only way to bring about stability in the exploitation of the environment so that it could be secured for the future generations. It defined sustainable development as development that meets the needs of the present without compromising the ability of future generations to meet their own needs (United Nations General Assembly, 1987, p. 43). The three major areas which come under the title of sustainable development are 
the economic, social, and environmental concerns. Although the concept of sustainable development has been recently brought in, the awareness towards the environmental crisis has been pointed out quite early from the time of mid-ninetieth century and the world wars. There were writers like Henri Barbusse (1873-1935), Ernst Junger (1895-1998), Freidrich Engels (1820-1895), George Mosse (1918-1999) who wrote about the environmental problems. The issue of environmental problems and the degraded atmosphere was a major topic of discussion in science, philosophy, sociology, and literature. A similar movement towards sustainable development was started in the field of literature under the title of ecocriticism $^{1}$. It is a study of the relationship between literature and the physical environment (Barry, 2009). Ecocriticism also has its literary relevance from the writers like Ralph Waldo Emerson (18031882), Henry David Thoreau (1817-1862), Margaret Fuller (1810-1850). Some of the important writings which can be read in the light of ecocriticism are James Thomson's The Seasons (1730), Thomas Grey's Elegy in a Country Churchyard (1751), William Cowper's The Task (1785), Wordsworth's The Prelude (1805), T. S. Eliot's The Waste Land (1922). The paper attempts to concentrate on the degenerated parts of nature, which has been portrayed in the poems of T.S. Eliot. Eliot was an eminent figure of the twentieth century, whose works focus on the different issues of the modern period. Apart from the various topics, his works also venture into the mercilessness of man towards nature. The writer has projected the squalor of urban and rural ecological conditions. Eliot's projection of the cities devoid of foliage reflects his deep understanding of the adverse effects of industrialization and the aftermath of the two world wars, which reflects his concern on the loss of human-nature relationships. The paper is a reading of Eliot's poems through the ecocritical perspective and presents how Eliot had tried to create awareness among the readers, even in the present time. Eco critics believe that human existence in the world is not only based on society and language; nature also plays an important role in the development of human lives. In this context, Eliot's works reflect that man has degraded the natural environment for his own selfish needs. Anne Whitsun Sprin asserts that $n a-$ ture pervades the city, forging bonds between the city and the air, earth, water, and living organism within and around it (Sprin, 1984, xi). But Eliot's cities itself are on the verge of destruction and hence fail to create a bond between nature and the living organism around it.

\footnotetext{
1. Ecocriticism was a movement that started in 1980 s in USA and in 1990's in UK.
}

\section{Eliot and the Environmental Crisis}

In his early poems composed during the period 1917 to 1922 , Eliot has pictured the sordidness and squalor of the urban cities. It must be noted here that Eliot himself kept moving from one city to another at the time when the world was into its heights of progression. He could observe the natural environment turning into unnatural, which took shape in his poetry. Years later, Eliot asserted that I learned that the sort of material that I had, the sort of experience that an adolescent had had, in an industrial city in America, could be the material for poetry (Eliot, 1965, 126). In Love Song of J. Alfred Prufrock, the narrator has to walk down through the half deserted streets (Eliot, Prufrock, 04). The poet in the beginning of the poem has stated that modern cities have become unnatural and completely devoid of fertile land, fresh air, and freshwater. The yellow fog is spread all across the sky, which has degraded the city and made it a place devoid of fresh air, whereas towards the end of the poem, Eliot has mentioned the water as black and white (Eliot, 120), hinting at the contamination of the water. Eliot's French influence of Baudelaire's and Laforgue's images of urban decay and squalor helped him in understanding of the destruction of the urban environmental crisis. In Preludes, Eliot has portrayed the real picture of the unlawful relationships of modern men with nature. The poem begins at six o'clock in the evening with the smell of steaks in passageways (Eliot, Preludes, 02) and the burnt out ends of smoky days (Preludes, 04). Though, there are two different time periods in the poem, the evening and the morning, which reflects that modern city is completely contaminated and polluted, and there is no scope of a healthy environment to live in. The city could only offer waste and dirt such as the grimy scraps (Preludes, 06), withered leaves (Preludes, 07), newspaper from vacant lots (Preludes, 08). The broken blinds (Preludes, 10) and chimney pots (Preludes, 10) reflect that the city has no fresh air to breathe in. The morning comes with faint stale smells of beer (Preludes, 15) and the sawdust trampled street (Preludes, 16). Eliot has delineated an image of nature, which has degenerated into nothing more than squalor. His picture of nature stands in contrast with what William Wordsworth has presented about nature in his poems:

Whose dwelling is the light of setting suns, And the round ocean and the living air, And the blue sky, and in the mind of man (Wordsworth, Tintern Abbey, 97-99).

Wordsworth, in his poems, seems to celebrate nature. He has portrayed nature as peaceful, calm, and pollution-free. 
Eliot, in his essay The Idea of a Christian Society, asserted the problems of the growing industrialization, saying that in a country that is extremely industrialized, there can be materialistic philosophy in it, which will be more threatening. Britain is highly industrialized, which has created the bodies of men and women-of all classes-detached from tradition, alienated from religion and susceptible to mass suggestion: in other words, a mob (Eliot, 1939, p. 17). Eliot's works depict the monstrous effects of industrialization and commercialization over the natural environment and human lives. There are references to smoke that falls from chimneys (Eliot, Prufrock, 19), smoke that slides along the street (Prufrock 24), smoke that rise from pipes (Prufrock, 71), smoke and fog of a December afternoon (Eliot, Portrait, 01) the burnt out - ends of smoky days (Eliot, Prelude, 04), which reflect that modern city is dirty, polluted and suffocating. The continuous reference to smoke and fog in his poems can be traced back to his memory of childhood in St. Louis. Eliot could witness the city turning into a desolate land by the effects of commercialization. The industries which were set up in the city had turned it into a desolate place. The Mississippi river, which inspired the poet all through his life, also turned sluggish between two banks of yellow mud (Ackroyd, 1984, p. 23). On the Internet, one can easily find the picture of The Eads Bridge, opened in 1874 as the first St. Louis Bridge over the Mississippi River. It is a reflection of the brutal effects of industrial construction over the Mississippi River. It affected the poet's childhood days. Eliot could find on Locust, and in the nearby streets, almost no population remains, everything having become shoddy commercial development, or having sunk into ghastly dereliction (Kirk, 1971, p. 18). Eliot has frequently mentioned the street in his poems. The streets are overcrowded day and night with fog and smoke of the industries and factories which resonate horns and motors' sound. Most of his characters are the city dwellers who wander in the streets of the city. This idea has also been pointed out by Rajni Singh in her book Tennyson and T.S. Eliot: A comparative Study. She states that:

The sound of 'horns and motors' (1.197) and the crumbling brothels and bar suggest squalor. The river is polluted by the biproducts of the factories. It sweats oil and tar. Owing to the smoke coming out from the chimneys, the trees have become dusty (Singh, 2005, p.173).

The street also focuses on urbanization. The development of huge cities and towns has led to deforestation, which is leading modern men towards the destruction of the environment.

\section{An approach towards Sustainable Development}

Eliot's masterpiece The Waste Land is an epic poem which depicts Eliot's anxiety towards the serious environmental issues of the post war period of 1922 . The title of the poem hints at the idea that modern land has turned into a wasteland. Eliot, in this poem, has talked about multiple issues of environmental problems such as pollution, population, deforestations, and the crisis of water. The poem can be read as Eliot's approach towards creating a need for sustainable development. According to Archana Parashar:

Keeping in view the environmental con-
cerns of the present age, an ecocritical
reading of The Waste Land provides vari-
ous sources of wisdom contained in the dif-
ferent philosophies, cultures, traditions,
and myths so as to find an authentic and vi-
brant environmental discourse (Verma,
2018, p. 01). The issues raised in the poem can be read in parallel with the major environmental crisis of the present times, such as loss of crop and grazing land due to erosion, desertification, conversion of land to nonfarm uses, and factors - about 20 million hectares a year (CIEPM, 1999, 186). These problems are reflected at the very outset of the poem, which hints towards the issue of land erosion and desertification as the modern land has been pictured as a dead land (Eliot, WL, 02) with dull roots (WL, 04). The threat of the depletion of the world's tropical forests (CIEPM, 1999, 186), has been reflected in the images of the land that has turned into stony rubbish (Eliot, WL, 20) where there is no hope of any trees or branches to grow. The trees are dead with no leaves and cannot provide any shelter, the cricket no relief, and the dry stone no sound of water (WL, 2324).

Another issue which the poet raises is related to climate change. In the present times, climate change, probably related to the increasing concentration of greenhouse gases in the atmosphere (CIEPM, 1999, 186) has led to the variation in the climate. The growing pollution has affected the seasons. The poet has also reflected on the issue of climate change. April is the time of rejoicing and life, but the poet has stated it as the cruellest month (Eliot, WL, 01). Similarly, spring and summer cannot be the time of rain, whereas winter is presented as a period of warmth. Eliot is reflecting on global warming, which is affecting the seasons.

The next issue related to the environmental crisis is the shortage of freshwater resources (CIEPM, 1999, 186). Eliot in The Waste Land has mentioned the contamination of the rivers and scarcity of water. 
Rivers are considered to be the source of life, but according to Eliot, the pollution and the dirt of modern society has affected the rivers. In the opening lines of the third section, The Fire Sermon, Eliot has pictured the degraded state of the river Thames in London. The bank of the river Thames is presented as barren where there are no trees for shelter. The land which surrounds the river is the brown land (Eliot, WL, 174), which symbolizes that there is no vegetation beside the river. Moreover, the spirituality of the river has also been destroyed as the poet says the nymphs are departed (WL, 03). It depicts a picture that is quite different from the one presented by Edmund Spenser in Prothalamion (1596). The river now bears empty bottles, sandwich papers, Silk handkerchiefs, cardboard box, cigarette ends (WL 176-179). Waggoner comments that this description not only hints at the machine-age squalor alone but they appear as symbols of the state of mind of modern dehumanized man (Waggoner, 1943, p. 117) who cannot see the harmful effects of the contaminated river. Rivers symbolizes sustenance of human life, but Thames in modern times has turned lifeless, and it sweats Oil and Tar (Eliot, WL, 266). Eliot's presentation of the river Thames can again be contrasted with how William Wordsworth has presented the river as all bright and glittering in the smokeless air (Eliot, 1802). The dirt and the pollution of the rivers, which he has reflected in his poems, are related to his own experience of the Mississippi river of St. Louis. Eliot could spend hours beside this river, and he could observe the serenity of the city being replaced by rapid industrial activities. Eliot has also mentioned the picture of Lake Geneva as a dull canal (Eliot, WL, 189), which flows beside a gashouse. There is a sharp comment in the final section of the poem where Eliot says that Ganga was sunken (WL, 396). Eliot, in these lines, tries to connote that though India has always been a rich source of cultural heritage and moral values, a country where rivers are treated as Goddess, but the selfish interest of man has made the river dirty and filthy. The final section of the poem is of more significance where Eliot foresees, one of the major problems of the future generations. In What the Thunder Said, Eliot talks about the scarcity of water, where he mentions that Here is no water but only rock/ Rock and no water (WL, 331-332). Eliot laments that there is only sterile thunder in the modern land, which has no hope for rain. The poet tries to hint towards the future crisis of water when men would desire just the sound of water. The whole section signifies drought, where the limp leaves waited for rain (WL, 96). The rapid Population growth (CIEPM, 1999, 186) across the world today is leading towards the continuous depletion of natural resources and also destruction to the environment. In this sense, the city has an essential relationship with the natural environment. But Eliot has depicted a city which has become unreal due to the overpopulation. These are the cities of
Falling towers Jerusalem, Athens, Alexandria, Vienna, London (Eliot, WL, 374-376), which are under the sway of urbanization and are overpopulated and have become a scary place for men to survive in. The poet continuously asserts that modern cities have become overcrowded and are thus under threat. The line A crowd flowed over London Bridge so many (WL, 62) and the London Bridge is falling down falling down falling down (WL, 427) hints towards the idea of urbanization and overpopulation which is again a serious environmental crisis today.

Extinction of Species (CIEPM, 1999, 186) is yet another problem which the world is facing today. Eliot also seems to focus on this aspect apart from his concerns towards the natural environment. He talks about the issues of biodiversity. The dirt and the squalor of the city, including the modern inventions, have also endangered the lives of the animals. This idea has been illustrated in the article Today's Environmental 'Waste Land': Eliot's Prediction of the Current Ecological Crisis. The cricket gives no relief as he himself is not getting shelter and is living on a dead tree with no leaves. Similarly, the dogs are domestic animals, but have been warned to stay away from men. The crisis of waters has affected the lives of Cicada and the hermit-thrush that are also yearning for water. The nightingale is singing in a deserted land, which symbolizes the deadness of both nature and animal, which again is a serious issue.

Moreover, in the second section of the poem The Game of Chess, Eliot has sharply pointed out the cause, which is leading towards the horrifying situation of environmental crisis. The poet has pictured modern men and women as lifeless beings who are, in a way destroying the atmosphere by their oblivion and disrespect attitude towards nature. There is no communication between men and women, and hence there is a dearth of harmony with nature. The section gives a grim message that modern men are more focused on artificiality and have lost their connection with nature and the environment. The image such as the burnished throne, Glowed on the marble, glitter of her jewels, strange synthetic perfumes, and drowned the sense in odours (Eliot, WL, 87-89) reflects that man is completely biased towards materialism and physical beauty and has lost the spiritual sense of protecting the nature.

The concepts of eco criticism of the present times were deeply rooted in the philosophy of Buddhism, Vedas, and Upanishad. Eliot was also inspired by the philosophies of Hinduism and Buddhism right from his Harvard years, where he came in contact with the great philosophers like Irving Babbit and George Santayana. Mahayana Buddhism teaches that nature and animals are equally important as human beings and the existence of one is important for the existence of the other. Eliot's allusion to the Buddhist philosophy of suffering, detachment, and the cultivation of compassion (Parashar, 2015, 165) is his idea of 
leaving the readers with a message to develop harmony with nature.

\section{Conclusion}

The study of T.S. Eliot through an ecocritical perspective is not only an approach towards understanding the major environmental issue of modernization, but also an awareness towards sustainable development. Eco criticism focuses that man and nature are interdependent. Human beings, from their birth, enjoy the benefits of nature. Eliot's major focus is to point out that man, in return, has turned out to be a selfish creature whose insensitive approach towards nature is exploiting it. Eliot, in his early poems, had talked about the dirt and squalor of the city, which affected the environment, whereas he has focused on important environmental crises in The Waste Land. Eliot, in his poems, has nowhere mentioned the green foliage, the flora, or the vegetation. He has mentioned the modern land as dead and decayed where no foliage can ever exist. He is nostalgic about the barrenness of the modern environment. Eliot, in his essay Notes Towards Definition of Culture stated that We are destroying our ancient edifices to make ready the ground upon which the barbarian nomads of the future will encamp in their mechanized caravans (Eliot, 1948, 185). Thus, his poem in a sequence from early poems to The Waste Land helps in understanding the poet's concern for environmental degradation. Perhaps in composing these poetic pieces, he intended to create an awareness of the major environmental problems and need for the sustainable development.

\section{References}

1. A Simple Guide into Ecocriticism, https://www.aresearchguide.com/ecocriticism.html. (23.01.2020).

2. ACKROYD P., 1984, T.S.ELIOT: A Life, Simon and Schuster, New York.
3. BARRY P., 2009, Ecocriticism, Beginning Theory: An Introduction to Literary and Cultural Theory, Manchester University Press, New York.

4. Committee on Industrial Environmental Performance Metric, 1999, The Sustainable Enterprise Paradigm Shift, in: Industrial Environmental Performance Metrics: Challenges and Opportunities, National Academy Press, Washington DC, https://www.nap.edu/ read/9458/chapter/13

(25.01.2020).

5. ELIOT T.S., 1939, 1948, Christianity and Culture: The Idea of a Christian Society and Notes towards the Definition of Culture, Harcourt Brace and Company, New York and London.

6. ELIOT T.S., 1965, To Criticize the Critic, and Other Writings, Faber \& Faber, London.

7. ELIOT T.S., 1969, The Complete Poems and Plays of T.S.Eliot, Faber and Faber, London.

8. KIRK R., 1971, Eliot and his age: TS Eliot's moral imagination in the twentieth century, Wilmington, Delaware, US.

9. PARASHAR A., 2015, Reverberations of Environmental Crisis and its Relevance in Managing Sustainablity: an Ecocritical Reading of T.S. Eliot's The Waste Land, in: Cross Mark, 42(2), p. 159-172.

10. SINGH R., 2005, Tennyson and T.S. Eliot: A Comparative Study, Sarup and Sons, New Delhi.

11. SPIRN A.W., 1984, The Granite Garden: Urban Nature and Human Design, Basic Books Inc, New York.

12. Today's Environmental 'Wasteland' Eliots Prediction of the Current Ecological Crisis https://grades fixer.com/free-essay-examples/todays-environmental-waste-land-eliots-prediction-of-the-current-ecological-crisis/ (24.01.2020).

13. VERMA A., 2018, Concept of Eco-Criticism in T S Eliot's Poetry, in: Quest Journals, Journal of Research in Humanities and Social Science, 6(2), p.0103.

14. WAGGONER H., 1943, TS Eliot and the Hollow Men, in: American Literature, 15(2), p. 101-126.

15. WORDSWORTH W., 1798, Lines Written a Few Miles above Tintern Abbey, in: Lyrical Ballads, Routledge.

16. WORDSWORTH W., 1802, Composed upon Westminster Bridge, Earth 1. 
